\title{
Promoting Sustainability through Web Service for Materials
}

\author{
Sooknyung Ha \\ College of Design, Sangmyung Univ., Cheonan-si, Chungcheongnam-do, South \\ Korea \\ snha3430@smu.ac.kr
}

\begin{abstract}
The purpose of this study is to find a direction for building a web service environment developed for reused materials for sustainable spatial design. Building the strategic website utilizing flexible spaces and reused materials can cope with environmental changes in the 21 st century, meet social demands, and seeks to provide potential values through the differentiated website systematized in pursuing a design that transforms into an innovative and original space, although it uses old spaces and materials. In particular, it is meaningful to provide customized reused materials that users want as a way to easily reuse materials left unattended or discarded due to overproduction in this age of information. The steps to develop a specific web process model are as follows. First, understanding the current status of Internet websites of domestic and foreign companies related to reusable and recycled finishing materials for sustainable spatial design. This is in order to construct a concrete web service model for sustainable spatial design through advanced web cases currently being implemented. Second, activating the reused materials utilization necessary for sustainable spatial design through solving more substantial and realistic problems using an FGI survey. Third, presenting materials utilization process of the website for self-evaluation and monitoring. This step is intended to build a web service model centered on the website by drawing out plans and ideas for the smooth use and dissemination of the website." In the end, for reused materials utilization in space, the principle of the right place is necessary to receive the needed resources by shipment or direct collection through a network agreement. Through the realization of the developed website, we intend to lay the foundation for contributing to the activation of sustainable spaces being able to protect the environment, have a social responsibility, and have economic values by creating a design environment for planning sustainable spaces, and expanding users' participation and disseminating the website in the future.
\end{abstract}

Keywords: Sustainability, Web service, Materials

\section{Introduction}

According to Oxford English Dictionary revised in 2002, the word 'sustainable' is defined as, "human economic activity and culture to preserve the environment, and development and use through compatible ways of preserving the environment and natural resources for future generations". In addition, the term currently places emphasis on environmental responsibility, and is used interchangeably with similar expressions such as 'eco-friendly', 'Eco', and 'Green' when referring to the concept. However, while 'Green' and 'Eco' refer to approaches or

Article history:

Received (October 23, 2020), Review Result (November 29, 2020), Accepted (January 2, 2020) 
design methods that mainly focus on the environment and take into account environmental influences such as materials, technologies, and marketing applied in the product design process, 'Sustainable' differs in its approach in terms of environmental, social and economic impacts of materials, designs, and production processes as well as reuse of resources that can be continuously recycled after disposal.

In this regard, the researcher wanted to differentiate the fact that the reused materials in this study are recycled in spaces without reprocessing.

This study was conducted under the premise that it can be used as a facilitator for the creation of a sustainable space. The ultimate purpose of the website development is to spread practical consumerism, practice responsible consumption, create sustainable values and spread sharing, have a sense of community, increase consumers who choose from common interests and perspectives, increase space regeneration, and increase reuse of waste resources, increase economic values, and form a network among designers, architects, markets, and institutions [1].

The table below summarizes the content of interviews and theories of experts from various levels who argued the necessity of website development of reused materials [Table 1].

Table 1 . The need for website development for sustainable material use

\begin{tabular}{|c|c|}
\hline Author & Contents \\
\hline $\begin{array}{c}\text { Césare } \\
\text { Peeren/2012Architectem }\end{array}$ & $\begin{array}{l}\text { 'Recycle.net' is a design online community that informs the location of } \\
\text { various final products, and introduces them separately by material, concept, } \\
\text { art, product, architecture, and media, among which the pieces presented by } \\
\text { material are described in detail for easy understanding. In particular, by } \\
\text { developing a map on the web, the location of the demolition site can be } \\
\text { quickly checked in real time and the desired material can be shipped[9]. }\end{array}$ \\
\hline $\begin{array}{c}\text { Shin Chi-ho (2019)/RE(Rescue } \\
\text { Earth) }\end{array}$ & $\begin{array}{c}\text { Shin Chi-ho, CEO of 'RE', an eco-friendly design group in Korea, mentioned } \\
\text { the necessity of web services for reuse design to secure materials and } \\
\text { improve procurement methods, develop a website that allows you to see } \\
\text { materials of various types and sizes at a glance, improve the system of the } \\
\text { distribution process, and prepare a material platform on- and off-line through } \\
\text { a direct interview. }\end{array}$ \\
\hline $\begin{array}{l}\text { Park Seung-bae et al. (2019)/ } \\
\text { Consumer behavior }\end{array}$ & $\begin{array}{l}\text { They said that as a user-led participation environment for design is created } \\
\text { online, and the barriers to the entry into the design become flexible, user } \\
\text { experience is getting more important. The design production method has } \\
\text { changed from the existing face-to-face one-way order-made to a non-face-to- } \\
\text { face two-way communication service. This allows users to use platforms } \\
\text { without time and space constraints, and platform companies, which are } \\
\text { service providers, are making ceaseless efforts in R\&D to provide more } \\
\text { efficient interfaces to users [2]. }\end{array}$ \\
\hline $\begin{array}{c}\text { Marshall W. Van Alstyne et al. } \\
\text { (2016) }\end{array}$ & $\begin{array}{l}\text { They defined the meaning of the platform in the 4th industrial revolution era } \\
\text { as producing results with smart and sophisticated software tools that can } \\
\text { connect producers and consumers more accurately, easily and quickly as } \\
\text { well as digital technology that can break down the walls of time and space } \\
\text { [3]. }\end{array}$ \\
\hline
\end{tabular}

\section{Research trends at home and abroad}

\subsection{Sustainability}

In the case of previous studies subject to sustainable spatial design, research on sustainable spatial design, comparative analysis of green certification system, eco-friendliness evaluation, and the expressional characteristics of design has been continuously conducted, but research 
on sustainable space applied with reused materials is limited to a very small part, and there is almost no research on a new creative design paradigm from the perspective of regenerating old and abandoned spaces and materials rather than focusing on a new space. Ernesto van Peborgh \& the Odiseo team defined the factor for paradigm shift of sustainability as responsible consumption of consumers, the natural environment preservation (conserving the ecosystem), restoring ethic and credibility of government agencies, corporate social and environmental responsibility, long-view design, reuse, cycled design, optimization process, innovative design, interaction and network value creation. In other words, due to the new paradigm of sustainable, users are no longer focused on consumption issues, but are integrating ethical issues and social values, and recognize the importance of new technologies and processes that reduce the economic, social and environmental impacts.

\subsection{Realize an online-based website for sustainable spatial design}

Césare Peeren is the founder of the Dutch design group '2012 Architecten'. His design strategy is to recycle or reuse materials, and to promote reuse, 'recyclicity.net' was first established in 2003, which was developed into 'Superuse' in 2007. 'Superuse', as a design online community that informs the location of various final products collected to make new raw materials instead of being sent to a landfill or incinerator, it introduces them separately by material, concept, art, product, architecture, and media. Among them, the works presented by material are explained in detail for easy understanding. In particular, it informs the location of the demolition site to be checked quickly in real time and the desired material to be shipped by developing a map on the web. After all, materials and products are not extinct, but reinvented in a continuous cycle of creation and re-creation. Because they provide potential values for creating new spaces and products, the purpose of the design is a strategy to promote the transition to a sustainable society [10].

Shin Chi-ho, CEO of'RE', an eco-friendly design group in Korea, mentioned the necessity of web services for reuse design to secure materials and improve procurement methods, develop a website that allows you to see materials of various types and sizes at a glance, improve the system of the distribution process, and prepare a material platform on and offline through a direct interview.

Marshall W. Van Alstyne et al. defined the meaning of the platform in the 4th industrial revolution era as producing results with smart and sophisticated software tools that can connect producers and consumers more accurately, easily and quickly as well as digital technology that can break down the walls of time and space [3].

\subsection{Analysis of 'Superuse' website based on reused materials}

'2012 Architected' selected and designed reused materials and is disseminating and expanding them as a measure for environmentally sustainable design in the current situation where urbanization and global warming are megatrends. The map called 'Harvest Maps' of 'Superuse' they developed helps to avoid inefficient transport and distribution procedures because it has the function to select and display only materials close to one specific place. Also, they are committed to reuse as an "integrated design strategy". Reused materials are the repeated use of materials and products [5]. This can be an alternative that can reduce the use of natural resources as much as possible, and is in context with the environmentally sustainable design they pursue [6]. Reused materials already play an important role in the construction industry from structural elements to surfaces, and reused subsidiary materials are currently being used as an alternative to major products or architectural materials. In the 
process of reused materials, each waste is dismantled or sorted, then reprocessed to be reused, which helps to save time, money, energy and resources.

Superuse' is a design online community that informs the location of various final products collected to make new raw materials instead of being sent to landfills or incinerators, providing information so designers can find the specific parts they need. Furthermore, it serves as a source that informs where and how the industrial products or discarded after use can be used now, and various examples of reused materials applied are shared.

In addition, it is establishing a strategy for environmentally sustainable interior design by presenting various design contents in relation to the theme of reuse. The main content is introducing works separately by material, concept, art, product, architecture, and media, among which the pieces presented by material are described in detail for easy understanding. This gives life by reusing and transforming discarded wastes, and at the same time reinvented into a design with a new purpose. [Figure 1]

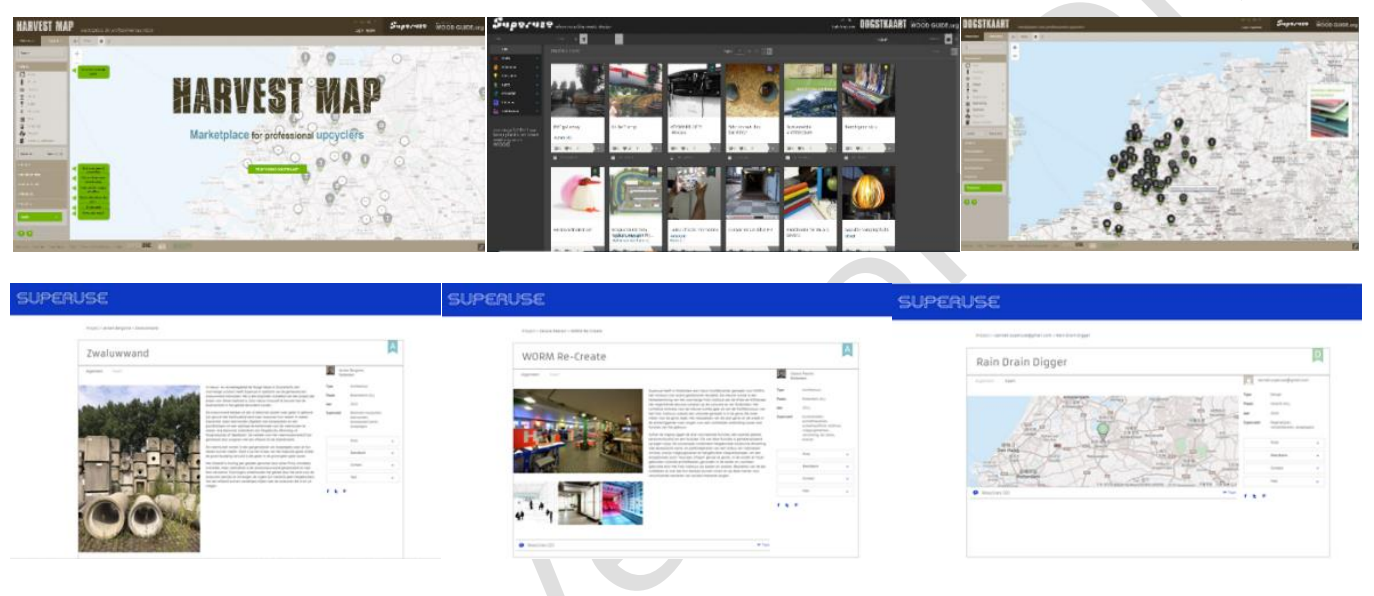

Figure 1. 'Superuse' Website [11][12][13]

\subsection{User needs for reused materials and the website}

Subjects of the FGI survey consisted of 5 teams of 4 people in an actual consumable class with a high interest in eco-friendly, reusable, and sustainable spatial design. Researchers conducted a workshop based on the questionnaire, creating an atmosphere so that opinions by group could be freely expressed, and the results are summarized.

As a result of the FGI survey, we could find the answer to problems that we tried to verify from various opinions of each group. For each discussion result of the five groups, a common opinion was judged as a definite answer to a question, and the summary of steps for each group is as follows.

As a method of collecting information on reused materials, there are cases of accessing reused materials with the help of others as well as direct Internet access. In addition, since the intention to use reused materials in spatial design is positively presented, activating web information was found to be essential to increase the efficiency of sales and purchase of reused materials. They lacked information on reused materials and felt limitations for applying them in spatial design. The lack of website information on a place where to buy or sell the reused materials remains regret in the Internet society in this 21 st century. 
Table 2. Necessaries to actively apply reused materials

\begin{tabular}{|c|c|}
\hline Classification & Summaries \\
\hline Questions & What do you think is difficult to apply reused materials to space design? \\
\hline Group 1 & Complex processing, difficulty in purchasing materials, and a lack of technology \\
\hline Group 2 & A lack of information on a website provided and lack of technology \\
\hline Group 3 & $\begin{array}{c}\text { A lack of existing cases, lack of information on materials, lack of information on a website } \\
\text { provided, etc. }\end{array}$ \\
\hline Group 4 & $\begin{array}{c}\text { Difficulties in purchasing materials, lack of information on materials, lack of existing cases, } \\
\text { etc. }\end{array}$ \\
\hline Group 5 & $\begin{array}{l}\text { A lack of existing cases, lack of information on materials, lack of information on a website } \\
\text { provided, etc. }\end{array}$ \\
\hline Sub-results & $\begin{array}{l}\text { Due to a lack of existing cases the subjects have a difficulty to apply the reused materials to } \\
\text { the space design. Due to a lack of information on reused materials, they feel the limitations on } \\
\text { applying them to space design. There is a considerable difficulty due to a lack of information } \\
\text { on websites that provide dealers or vendors of the reused materials. }\end{array}$ \\
\hline Classification & Summaries \\
\hline Questions & $\begin{array}{l}\text { What conditions do you think are necessary to actively apply reused materials to space } \\
\text { design? }\end{array}$ \\
\hline Group 1 & $\begin{array}{l}\text { The demand for reused materials is required and the types should be diversified. In addition, } \\
\text { specialists, expertise, professional training and management measures for the use of reused } \\
\text { materials are required. }\end{array}$ \\
\hline Group 2 & $\begin{array}{l}\text { The types should be diversified and it needs active use of web information. In addition, } \\
\text { specialists and professional training for the use of reused materials are required. }\end{array}$ \\
\hline Group 3 & $\begin{array}{l}\text { Specialists, expertise and active use of web information are needed. In addition, the types of } \\
\text { reused materials should be diversified and the demand for them is required. }\end{array}$ \\
\hline Group 4 & $\begin{array}{l}\text { The types of reused materials should be diversified. In addition, detailed guidelines, expertise, } \\
\text { and management measures for th use of reused materials are required. }\end{array}$ \\
\hline Group 5 & $\begin{array}{l}\text { Specialists, expertise, and professional training for the use of reused materials are required. In } \\
\text { addition, management measures for reused materials and active use of web information are } \\
\text { needed. }\end{array}$ \\
\hline Sub-results & $\begin{array}{l}\text { Most of the subjects think that in order to actively apply the reused materials to the space } \\
\text { design, various kinds of reused materials should be prepared as well as the demand of the } \\
\text { reused materials should be secured. In addition, specialists, expertise, professional training } \\
\text { and management measures for the use of reused materials are required. Especially, activation } \\
\text { of web information can increase sales and purchasing efficiency. }\end{array}$ \\
\hline
\end{tabular}

\section{Conclusions}

The main results obtained through the FGI survey by concurrently confirming and verifying preceded statistical survey results on perception, preference, experience, etc. for reused materials are as follows. First, in the statistical survey results $48 \%$ of respondents perceived reused materials as moderate, and in the FGI survey respondents also knew reused materials above moderate. Second, in order to apply reused materials to spatial design, detailed guidelines and maintenance plans for reused materials were found to be essential elements in statistical survey results, while it was necessary to secure the demand for reused materials as well as diversify the types of reused materials in the FGI survey results. Third, when applying reused materials to spatial design, most respondents said that eco-friendliness, price, and harmony with surroundings should be considered. In addition, when selecting reused materials, respondents in the statistical survey prioritized low price, easy maintenance and long-term use materials, while respondents in the FGI survey wanted to select ecofriendly materials that can be used for a long time and are easy to maintain, and are 
inexpensive, considering design, color, and structure. Finally, in the case of construction using reused materials for spatial design in the future, respondents in the FGI survey stated that reused materials should be able to be used for a long time, be easy to dispose of and be easy to maintain. 2]

The steps of online web service reflecting the results of the survey are as follows. [Figure.

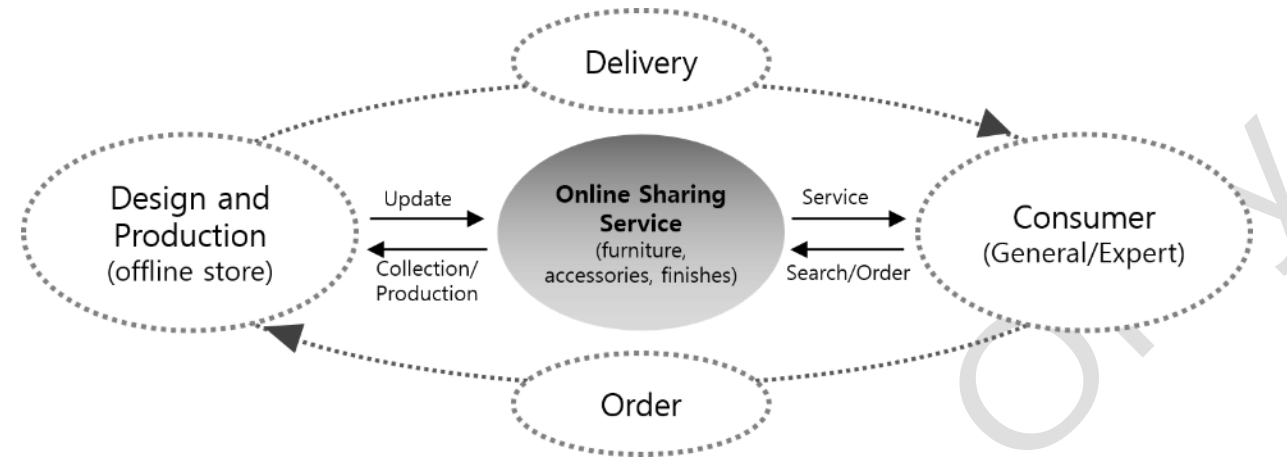

Figure 1. Steps of online web service of materials

For the utilization of reused materials in space, the principle of the right place is necessary to receive the needed resources by shipment or direct collection through a network agreement [7]. In order to establish insightful sustainable design in the future through this study, it is necessary to create a new axis of sustainable design for balanced development by forming the axis of social network and consumer participation [8]. Through the realization of the developed website, we intend to lay the foundation for contributing to the activation of sustainable spaces being able to protect the environment, have a social responsibility, and have economic values by creating a design environment for planning sustainable spaces, and expanding users' participation and disseminating the website in the future.

\section{References}

[1] J. Louise, "Environmentally responsible design," Jon Wiley \& Sons, Inc. pp.101-103, (2008)

[2] S.B. Park, "Consumer behavior," Myungkyungsa, pp.97-99, (2019)

[3] M. W. Van Alstyne, and S. P. Choudary, "Platform revolution : how networked markets are transforming the economy and how to make them work for you," Geoffrey G. Parker, pp.55-61, (2016)

[4] W. Weber, Biokapiral(The Nature is the Economy), Berliner Taschenbuch Verl, pp.15-25, (2009)

[5] C. Sauer, "Made of new materials sourcebook for architecture abd design," Gestalten, pp.85-90, (2010)

[6] M. McBride, "Triple bottom line by design: leading as if life matters," Design Management Review, (2011)

[7] K. H. Lee, K. Lew, "Creativity research trends in Korea," Asia-Pacific Journal of Educational Management Research, (2017)

[8] J. H. Byun, S. Y. Kim, and J. H. Sa, "Internet of things based smart city services for the creative economy," International Journal of Smart Home, vol.10, no.7, pp.185-192, (2016)

[9] K. R. Merlino, "Building reuse: Sustainability, preservation, and the value of design(sustainable design solutions from the pacific northwest)," University of Washington Press, Washington State, pp.79-110, (2018)

[10] D. Song and Y. Kim, "A Study on the Direction of Sustainable Urban Regeneration through Bibo Feng Shui," Asia-pacific Journal of Convergent Research Interchange, vol.5, no.1, pp.47-56, (2019)

[11] S.N. Ha, "A model on the material circulation strategy for sustainable spatial design," The Asian International Journal of Life Sciences, vol.29, no.1, pp.303-313, (2020) 
[12] https://www.superuse.org/ Aug. 10, (2020)

[13] https://www.oogstkaart.nl/ Jun. 27, (2020)

[14] https://www.youtube.com/watch?v=XvpxABH1Dzo\&feature=email/ May.25, (2020)

[15] http://www.woodguide.org/ Jun.27, (2020)

[16] https://www.oogstkaart.nl/oogstkaart/ May.25, (2020) 
This page is empty by intention. 